\title{
Assessing the Distribution and Stem Densities of Sclerocarya birrea in Arable and Non-Arable Lands: A Case of Zimbabwe
}

\section{Kugedera Andrew Tapiwa*}

Department of Environmental science, Faculty of Agriculture and Environmental Science, Bindura University of Science Education, Zimbabwe *Corresponding Author: Kugedera Andrew Tapiwa, Department of Environmental science, Faculty of Agriculture and Environmental Science, Bindura University of Science Education, Zimbabwe.

Received: June 13, 2019; Published: July 08, 2019

DOI: $10.31080 /$ ASMI.2019.02.0302

\begin{abstract}
The objective of the study was to assess stem density of $S$. birrea in Vuravhi Communal Lands and coming up with a sustainable way of conserving the tree. Woody vegetation characteristics such as species composition and density were randomly measured by placing transect lines one in arable lands and the other in non-arable lands covering a distance of approximately $2 \mathrm{~km}$. Marula tree was recorded after every $100 \mathrm{~m}$. Tree diameter was measured using tape measure to get circumference which was later converted to diameter. Local people were included for easy identification of tree species. Both arable and non-arable lands in the study area were sampled within three randomly selected villages to measure stem densities. Higher stem density was recorded in arable lands $(7.1 \pm$ 1.6 stems $/$ ha) than ( $4.2 \pm 0.5$ stems $/$ ha) non arable lands. The Marula trees in arable lands had more mature females $(54.5 \pm 0.3 \%)$ than non-arable lands $(34.2 \pm 3.6 \%)$. There was however, no significant difference between stem densities in arable and non-arable lands. Stem densities were higher in Chirinda ( 4.55 stems/ha) and Chitsaka (3.2 stems/ ha) than in Tizai ( 0.67 stems/ha). There was no significant difference between stem densities along transect line 1 and $2(p=0.542)$. The study concluded that more Marula tree were available in arable lands than non-arable lands because farmers mainly maintain them as private properties. It is recommended that farmers must increase the tree density in arable lands through domestication.
\end{abstract}

Keywords: Stem Density; Land Use; Distribution; Sclerocarya birrea

\section{Introduction}

The indigenous African Marula (Sclerocarya birrea subsp. caffra) belongs to the family Anacardiaceae together with other species such as Mangifera indica (Mango) [1,2]. Sclerocarya birrea subsp. caffra is the most abundant Marula in southern Africa [2-5]. Marula is a large, single stemmed dioecious tree that grows to a height between 7 - $18 \mathrm{~m}[2,5,6]$. Male and female flowers occur at different trees. Female trees are those that bear fruits $[4,5,7]$. Male trees do not bear fruits and they only provide flowers for pollination.

There are three subspecies of $S$. birrea which are recognised in Africa which includes $S$. birrea subsp caffra, $S$. birrea subsp multifoliolata and $S$. birrea subsp birrea [5,7-10]. These subspecies are determined on the basis of gross inflorescence and folia characte- ristics $[8,11]$. Sclerocarya birrea subsp caffra has long petioles $[0.5$ $-3.0 \mathrm{~cm}$ ) of lower pairs of leaflets, acuminate or cuspidate leaflet apices and frequently longer (up to $22 \mathrm{~cm}$ ) inflorescences on male plants $[5,10]$. Sclerocarya birrea subsp caffra is the most ubiquitous and occur in Kenya, Tanzania (east tropical Africa), Angola, Malawi, Mozambique, Botswana, Zimbabwe (south tropical Africa) and Botswana, Namibia, South Africa and Swaziland $[6,12,13]$. The subsp. has also been recorded in Madagascar [13]. Sclerocarya birrea subsp caffra is recorded only in south of the Equator [3] (Figure1).

Important environmental factors in Marula distribution are mainly altitude, climate and soils [6]. Sclerocarya birrea is a constituent of medium to low elevation open woodlands [5,12]. Sclerocarya birrea subsp caffra is associated with a strongly seasonal rainfall pattern with mean annual rainfall of $200-1500 \mathrm{~mm}$ but 
higher population levels are found between 400 and $1000 \mathrm{~mm}$ $[3,4]$. Marula is common in hotter areas and is relatively drought - tolerant, which can survive in areas of low rainfall of about 200 mm per year [2,14]. Sclerocarya birrea subsp. caffra is sensitive to frost and its distribution is limited to frost prone area [3]. In southeast Zimbabwe and southwards into South Africa where frost sometime occur distribution of $S$. birrea is limited [2,7,15].

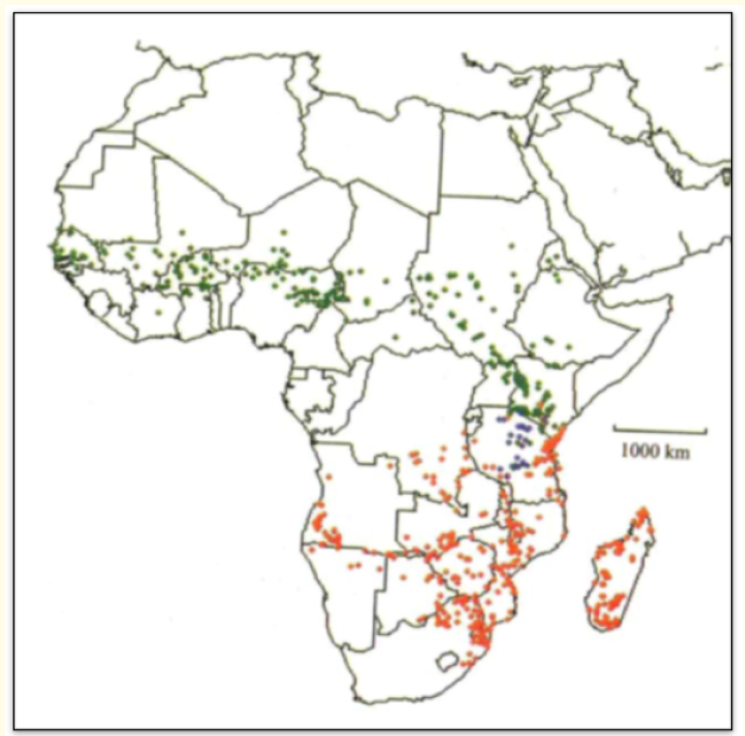

Figure 1: Distribution of Sclerocarya birrea: green - subsp. birrea; red - subsp. caffra; blue - subsp. multifoliolata

(Source: Hall et al. 2002).

\section{Methodology}

Study area

Field studies were carried out in four villages namely, Chirinda (ward 8) and Muchemwa, Musvuugwa and Tizai all located in Ward 11, Chivi. Some villages have no non-arable lands hence they use those to adjacent villages. This investigation is part of a large study aimed at documenting stem density of Marula in Vuravhi Communal Lands and Chivi District at Large. People in the study area speak Chikaranga, a dialect of Shona language. The area lies in agro-ecological region $1 \mathrm{~V}$ which is characterised by annual rainfall of between $450-650 \mathrm{~mm}$ a year, concentrated in the rainy season from Mid-November to March. In the coldest month, July mean temperature is around $10^{\circ} \mathrm{C}$ and $31^{\circ} \mathrm{C}$ in the hottest months which is October. The rainfall is unreliable characterised by severe mid-season dry spell which makes the area marginal for maize and other crops such as round nuts, ground nuts and sorghum. Rainfall is the greatest physical constraint to agricultural production, falling during a single season resulting in crop failure due to drought. Droughts are frequent and food insecurity is wide spread resulting to people relying most on wild fruits such as $S$. birrea fruits.

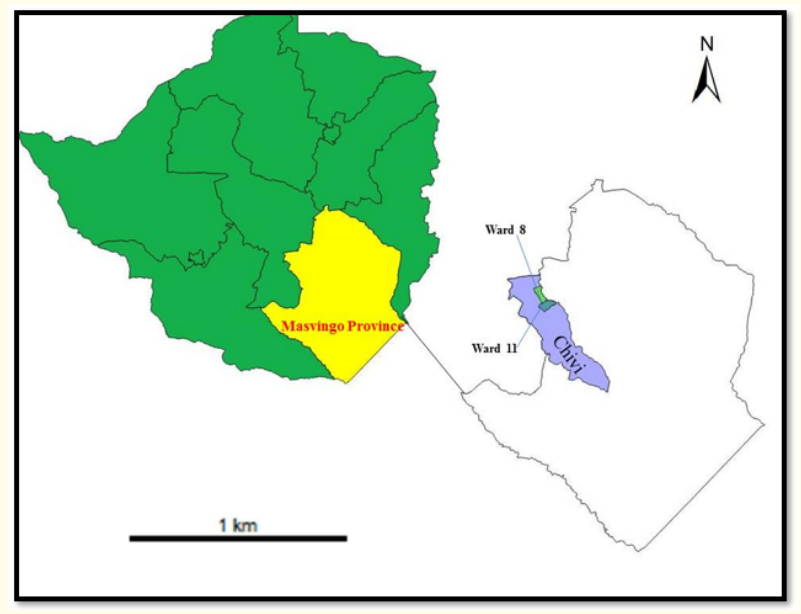

Figure 2: An approximate location of Vuravhi Communal Lands. Source: Chivi Rural District Council.

Soils are derived from granitic rocks giving rise to predominantly sandy loam soils with a low water holding capacity and low fertility. Subsistence farming is the mainstay livelihood of the population in Vuravhi Communal Lands. The area is characterised by savanna grasslands and savanna woodland types of vegetation with dry deciduous thicket in some parts. The woodlands provide firewood, poles, edible fruits, edible worms and thatching grass.

\section{Data collection}

The study and its objectives were first introduced to local traditional leaders to visit arable and non-arable lands. Once traditional leaders granted permission to proceed, mapping of arable lands and non-arable lands starts. Woody vegetation characteristics such as species composition, density and size structure were measured through placement of randomly positioned transects across the sampled villages. The purpose was to find the stem densities of Marula in both fields and grazing lands. Two transect lines were used one placed in arable land starting from a borehole at $180^{\circ}$ to the east and the other in grazing lands from Vuravhi Hill at $180^{\circ}$ to the east towards Tokwe River. Bearing and directions were measured using a direction compass placed in a hand. Measurement and 
recording of species in each transect line were done in two parts. Firstly selecting $S$. birrea trees in the transect line and their distance from central points. This made it possible to measure $S$. birrea tree in all sizes and classes including seedlings, saplings and mature trees. Secondly, measuring Marula diameter with tape measure using a formula ( $d=\frac{\text { circumference }}{\pi}$ ), where $\pi$ used was 3.142 .

Data analysis

Analysis of field data was done using Minitab version 14 and SPSS version 16 to obtain graphs. Differences between sites were examined via ANOVA after testing for normality. A completely randomised block design (CRBD) was used to determine the differences in vegetation characteristics between villages and land use types. A two way factorial was used to test for interactions. Student t-tests were used to compare tree density and tree diameter classes between arable and non-arable land use. For significant
ANOVA results, subsequent pair-wise comparisons were examined via Least Significant Difference. To detect differences between land use (arable and non-arable areas) a T-test was used.

\section{Results}

Stem population density in arable and non-arable lands Stem density in selected individual plots and fields

There was an increase in young stems as a result of active planting and nurturing of self-seed trees. In Mr Chirinda plot (which is approximately four hectares) there are six stems/ha of mixed sizes. There are 12 stems/ha Marula of which eight stems/ha did not produce Marula as they were at tender ages. About $11 \mathrm{stem} / \mathrm{ha}$ were mature with nine female plants and two males. Recruitment of Marula is now given value by rural communities. Table 1 shows Marula stems counted in some selected arable lands in Vuravhi Communal Lands.

\begin{tabular}{|l|c|c|c|c|}
\hline Name of farmer / Village & $\begin{array}{c}\text { Density } \\
\text { (stems/ha) }\end{array}$ & $\begin{array}{c}\text { \% mature (>12 cm } \\
\text { diameter) }\end{array}$ & $\begin{array}{c}\text { \%female } \\
\text { trees }\end{array}$ & $\begin{array}{c}\text { Female density } \\
\text { (trees/ha) }\end{array}$ \\
\hline Chirinda E. R (Chirinda) & $5.75 \pm 1.1$ & 15.2 & 39.1 & $2.3 \pm 1.3$ \\
\hline Magoga. P (Musvuugwa) & $9.5 \pm 0.9$ & 26.8 & 63.2 & $6.0 \pm 0.7$ \\
\hline Matingwina. J (Muchemwa) & $6.6 \pm 1.2$ & 24.1 & 60.6 & $4.0 \pm 0.4$ \\
\hline Vuravhi P. School & $8.3 \pm 1.3$ & 20.7 & 55.0 & $4.6 \pm 1.1$ \\
\hline Zvitare. J (Chirinda) & $4.7 \pm 0.7$ & 20.5 & 50.0 & $2.3 \pm 0.3$ \\
\hline Matsembe. Z (Tizai) & $7.3 \pm 1.4$ & 21.7 & 59.1 & $4.3 \pm 0.2$ \\
\hline
\end{tabular}

Table 1: Density of $S$. birrea under some selected plots from members of the community (Mean \pm SE).

Higher density of female Marula trees were recorded in Mr Magoga's field with 6.0 stems/ ha with some of the trees planted by his father as fencing poles. Most of the sampled plots had higher densities of mature Marula trees and mature female trees except Mr Chirinda's plot where there were Marula trees with less than $20 \mathrm{~cm}$ diameter compared to other farmers' plots greater than 20 cm diameter. Female density was low in Mr Zvitare and Mr Chirinda's plot compared to other plots, although mature trees in $\mathrm{Mr}$ Zvitare's fields were had higher density. On average Musvuugwa village had higher density (stem/ha) followed by Tizai and lastly Chirinda village (Figure 3).
The participants interviewed outlined that stem density of S. birrea is increasing (75.6\%) and $27.8 \%$ indicated that stem density is decreasing. Those who indicated that stem density of Marula is increasing supported their sentiments saying people are now following traditional rules against cutting down of Marula (18.9\%) with $40.0 \%$ suggesting that passive protection and nurturing of self seeded recruits causes an increase in stem density. Some mentioned that people are now educated and see the importance of Marula (13.3\%) and others are trying to reduce effects of deforestation. 


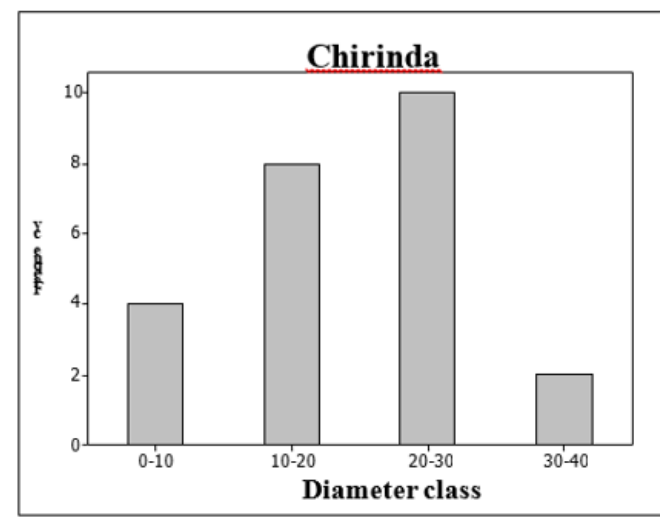

(a) Diameter class chart for Chirinda.

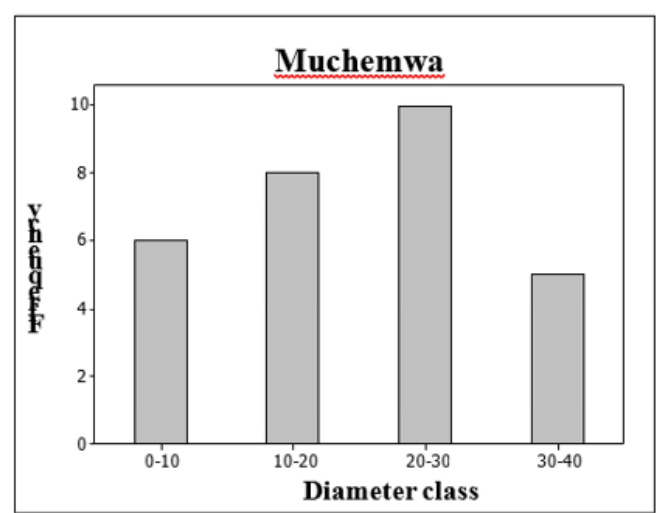

(c) Diameter class chart for Muchemwa.

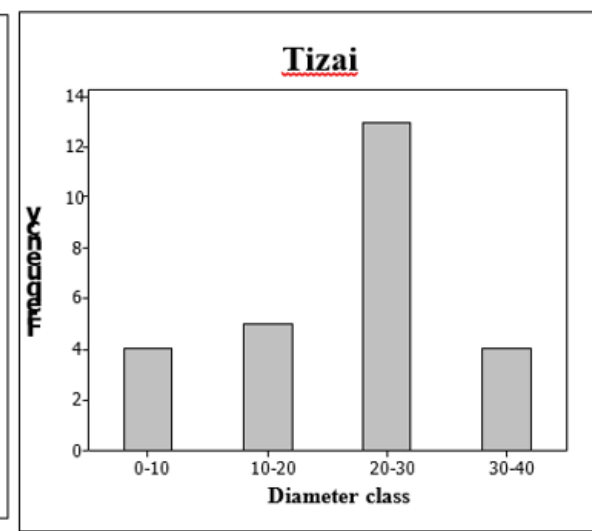

(b) Diameter class for Tizai.

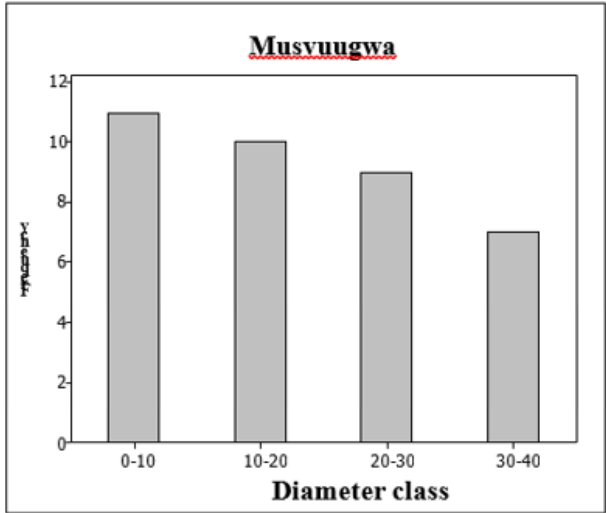

(d) Diameter class chart for Musvuugwa

Figure 3a-d: Diameter class charts for four villages.

\section{Stem population density in different land uses}

Examination of the absolute density of female trees indicated a difference between homestead plots and communal grazing lands. Relative to this figure, there was an approximately $46 \%$ lower density of mature female trees in communal grazing lands compared to household plots. Higher densities of mature female Marula tree were found in household plot (arable) with $54.5 \pm 0.3 \%$ compared to those in communal grazing lands (non-arable) with 34.2 $\pm 3.6 \%$ (Table 2). Mature trees with circumference greater than $43 \mathrm{~cm}$ were found in arable lands comprising $67.6 \pm 0.2 \%$ compared to $14.2 \pm 2.1 \%$ in non-arable lands. There are higher densities (stem/ha) in arable lands $(7.1 \pm 1.6)$ compared to $4.2 \pm 0.5$ but statistically there are no significant difference in stem densities $(\mathrm{P}=0.917)$. The major concern was based on Marula trees which produced fruits as they are the one smallholder farmers gave first preference. The density (stem/ha) of female Marula trees was 3.9 \pm 1.9 in household plot (arable land) and $2.1 \pm 0.5$ in communal grazing lands (non-arable lands) (Table 2).

\begin{tabular}{|l|c|c|}
\hline & $\begin{array}{c}\text { Household } \\
\text { plots } \\
\text { \% of trees }\end{array}$ & $\begin{array}{c}\text { Communal grazing } \\
\text { lands } \\
\text { \% of trees }\end{array}$ \\
\hline Density (stems/ ha) & $7.1 \pm 1.6$ & $4.2 \pm 0.5$ \\
\hline $\begin{array}{l}\text { \% Mature trees } \\
\text { (>15 cm diameter) }\end{array}$ & $67.6 \pm 0.2$ & $14.2 \pm 2.1$ \\
\hline \% Mature female & $54.5 \pm 0.3$ & $34.2 \pm 3.6$ \\
\hline $\begin{array}{l}\text { Female density } \\
\text { (trees/ ha) }\end{array}$ & $3.9 \pm 1.9$ & $2.1 \pm 0.5$ \\
\hline
\end{tabular}

Table 2: Density of $S$. birrea under different land uses (Mean $\pm \mathrm{SE})$.

There was no significant difference between mean stem density in arable (2.3 stems/ha) and non-arable (2.2 stems/ha) $(\mathrm{P}>0.05)$. The results also show that there are higher stem densities in arable land although there is no significant different between stem densities in arable and non-arable land. Results from T-test shows that there is no significant difference between stem density in arable and non-arable lands $(\mathrm{T}=0.64, \mathrm{P}=0.542)$. 
Stem population density in different villages (Chirinda, Chitsaka and Tizai)

There were higher stem densities in Chirinda followed by those in Chitsaka and Tizai respectively (Figure 4). There were no significant difference in stem density between Chirinda, Chitsaka and Tizai $(\mathrm{P}=0.40)$ but between villages were different using the LSD with $\mathrm{P}=0.05$.

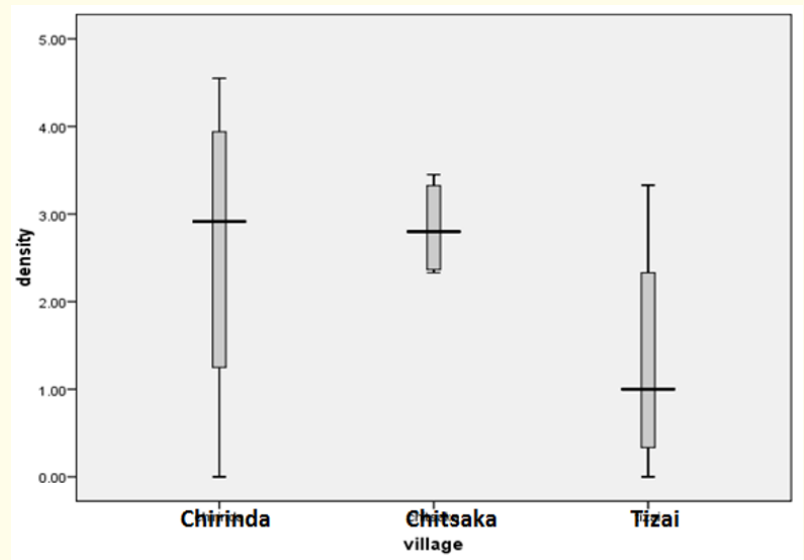

Figure 4: Stem density of Marula in three villages.
There were significant different in the means between Chirinda and Chitsaka $(\mathrm{P}=0.05)$ and were significantly different to that of Tizai $(\mathrm{P}<0.05)$. The results also shows that Chitsaka had higher stem density mean compared to all the three villages. There were higher stem densities in non-arable land of all three villages assessed (Figure 5).

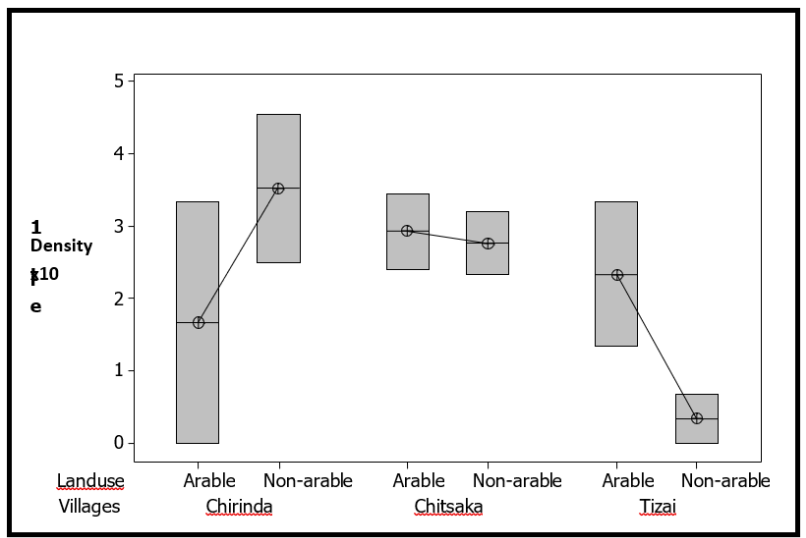

Figure 5: Box plot of interaction in stem density of villages and land uses.

\begin{tabular}{|c|c|c|c|c|c|}
\hline Village & $\%$ of arable & $\%$ of non-arable & $\begin{array}{l}\text { Transect number } \\
\text { in village }\end{array}$ & $\begin{array}{c}\text { Arable land (Marula } \\
\text { density/ha) }\end{array}$ & $\begin{array}{c}\text { Non arable land (Marula } \\
\text { density/ha) }\end{array}$ \\
\hline Chirinda & 57 & 43 & $\begin{array}{l}\mathrm{T} 1 \\
\mathrm{~T} 2 \\
\end{array}$ & $\begin{array}{c}0 \\
3.33\end{array}$ & $\begin{array}{l}4.55 \\
2.50 \\
\end{array}$ \\
\hline Tizai & 55 & 45 & $\begin{array}{l}\mathrm{T} 1 \\
\mathrm{~T} 2 \\
\end{array}$ & $\begin{array}{l}1.33 \\
3.33 \\
\end{array}$ & $\begin{array}{c}0.67 \\
0 \\
\end{array}$ \\
\hline Chitsaka & 60 & 40 & $\begin{array}{l}\text { T1 } \\
\text { T2 }\end{array}$ & $\begin{array}{l}2.40 \\
3.45\end{array}$ & $\begin{array}{l}3.20 \\
2.33\end{array}$ \\
\hline
\end{tabular}

Table 3: Summary of densities of Marula in Villages, land use and transect lines.

There were no significant differences between the interactions stem densities in villages and land use $(P=0.261)$. Stem densities in both arable land and non-arable land in Chitsaka village were closer to each other. Tizai village recorded the lowest stem density in non-arable land. In arable lands Chitsaka recorded higher stem densities followed by Tizai and Chirinda respectively. There were also no significant difference in densities between villages and land uses $(\mathrm{P}=0.363)$.

\section{Discussion}

\section{Stem density of Marula}

Higher densities of female $S$. birrea were recorded in homestead plots and fields of selected individuals since they are the ones which supply people with fruits, nuts and even kernels. The local appreciation of $S$. birrea as a key species is also evident in the proportion of households that have $S$. birrea trees in their homesteads 
and/or fields, $39.1 \%$ to $63.2 \%$ (Table 1). Similar results were reported in Namibia and South Africa were most households plots are surrounded with $S$. birrea trees especially mature female trees which produces fruits $[13,15,16]$.

The major reason for maintaining adult female $S$. birrea trees around homestead and fields is to guard against theft of fruits during the fruiting as this is the only major source of income apart from farming for people in Vuravhi Communal Lands. These results are comparable to those from Mozambique and KwaZulu-Natal Province in South Africa which also show that densities of $S$. birrea were high around homesteads and fields than in adjacent rangelands [4]. Adult female and male $S$. birrea trees are few in non-arable lands because people from various villages poach and cut them for firewood as Marula is one of the trees which is in large numbers compared to other species. This also coincides with results in Romwe catchment in the southern region of Chivi (Gerhardt and Nemarundwe 2005).

\section{Stem densities of Marula in different land uses}

Arable lands are under the influence of humans who can nurture and manages trees as they want. High stem density (stem/ha) in arable lands is due to the influence of humans who sometimes obey traditional rules which prohibits cutting down of fruits trees such as Marula which is a multipurpose tree. Non arable lands are now transforming to open access [17] where most community members grant permission to anyone to collect fruits and bark. Most people are now safeguarding Marula tree by managing those in arable lands. Although there was no significant difference between stem density in arable and non-arable, there are few Marula stems in non-arable lands. A declining density of male trees has implications for pollination success, which according to Leakey., et al. [9] already seems less but optimal. This was also an implication by Agricultural extension officers urging small-scale farmers to fell male trees in their homestead plots and fields as they bear no benefit to them leading to decline in adult male stem density [18-21].

\section{Marula Stem density in different villages and their} interactions

Higher stem densities are found in Chirinda village because most of the fields have been abandoned allowing recruitment of young Marula trees. Chitsaka village showed up a relatively higher density because is a large village with large arable lands compared to both Chirinda and Tizai (Figure 5). Low stem density in Tizai are relative to the size of the village. Although there is no signifi- cant difference between villages but the results clearly shows that higher stem densities are found in Chirinda followed by Chitsaka and Tizai respectively. Higher Marula densities were recorded in non-arable lands of Chirinda because people in the village are still obeying traditional rules and they do not cut young Marula trees in both arable and non-arable (Figure 5). Lower density was observed in non-arable lands of Tizai because they are clearing land for cultivation and extending their villages as they are still accommodating people from other villages (Figure 5). This also agrees with information obtained from Namibia [16] and South Africa [4].

Marula Stem density along transect lines and their interaction with land uses

Higher stem densities are generally found in non-arable lands because there are various stem sizes since no one disturbs new seedlings which can actually grow to become medium stems. The results show that many people in villages do not temper with young Marula trees in non-arable lands. This coincides with results from Namibia where people are not allowed to temper with young Marula trees [16]. Many people uses large Marula trees for firewood and carving paving way for young stems to grow. Lower stem densities along transect line two is because many people clear arable lands cutting all small stems to allow land for cultivation leaving large stems especially adult females which bear fruits [18].

\section{Marula Stem density in different land uses}

The density of adult female trees were found in arable lands because most farmers protects them as they bear fruits and used as shade by farmers during cultivation. The tree is sometimes used as storage places for plant remains. Farmers needs to maintain and keeps trees which benefits them directly or indirectly. Farmers also protect adult female trees because they are the ones which produce fruits from which income comes. Some traditional leaders have imposed rules which prohibits cutting down of female Marula trees, as the case in Namibia $[15,17]$

Adult male Marula trees have same density in arable and non-arable lands because people tend to clear them off in agricultural lands since they do not produce fruits. In non-arable lands people cut them for firewood and carving as well as poaching by other villages outside Vuravhi Communal Lands. In arable lands adult male are found in those fields far away from homesteads since they are used as storage facilities of crop residues which are useful for both humans and livestock. Density of juveniles is also equal in both arable and non-arable because they suffer competi- 
tion among themselves and also consumed by animals especially in non-arable areas. Seedlings are cut down during ploughing and cultivation in arable lands thereby reducing their chances of surviving. Only seedlings which emerge in ridges are the one which survive damage during ploughing and cultivation. Other researchers such as Shackleton., et al. [4] and Maroyi [2] produced same results to this research on high densities of adult females in homesteads compared to non-arable.

\section{Conclusions and Recommendations}

Higher densities of Marula tree were found in household plots because there are under conservation from plot owners and it is regarded as a taboo to cut fruit tree. Most farmers use this tree for various purposes. Higher densities in both arable and non-arable were of female tree as this bear fruits. Female trees are under protection. Most juvenile trees were found in Chirinda, Muchemwa and Musvuugwa with larger trees found in Tizai village since the village is closer to chief's homesteads. There need for government to impose forestry policy which will be well implemented using bottom-top approach. There is need for wider research to come up with factors causing a decline in density of Marula and what can be done to increase its density in both arable and non-arable. Most researchers on tackle density but did not go into depth about regeneration of the tree.

\section{Acknowledgements}

The researchers are indebted to Bindura University of Science Education and Rhodes University for their assistance with documents about Marula and assistance with field work, respectively. This study would not have been possible without the support and co-operation of the people of Vuravhi Communal Lands as a whole. Many thanks go to the Headmen of Vuravhi Communal Lands for granting permission to study in their area.

\section{Bibliography}

1. Hiwilepo van-Hal P. Processing of Marula (Sclerocarya birrea subsp. Caffra) fruits: A case study on health-promoting compounds in Marula pulp. Msc Thesis, Wageningen University (2013).

2. Maroyi A. "Local knowledge and use of Marula (Sclerocarya birrea (A. Rich.) Hochst.)”. In South-central Zimbabwe: Indian Journal of Traditional Knowledge 12.3 (2013): 398-403.
3. Hall J B., et al. Sclerocarya birrea: Monograph. School of Agricultural and Forest Sciences Publication Number 19, University of Wales, Bangor (2002).

4. Shackleton S E., et al. "Knowledge on Sclerocarya birrea subsp. caffra with emphasis on its importance as a non-timber forest product in South and southern Africa Part 1: Taxonomy, ecology and role in rural livelihoods". Southern African Forestry Journal 194 (2002): 27-41.

5. Ngorima G T. Towards sustainable use of Marula (Sclerocarya birrea) in the Savannah woodlands of Zvishavane District, Zimbabwe. A dissertation Submitted to the Faculty of Science, University of the Witwatersrand, Johannesburg, in partial fulfilment of the requirements for the degree of Master of Science in Resource Conservation Biology Johannesburg (2006).

6. Mokgolodi N C., et al. "The importance of an indigenous tree to Southern African communities with specific reference to its domestication and commercialisation: a case of the marula tree". Forestry Studies in China 13 (2011): 36-44.

7. Shackleton S E. The significance of the local trade in natural resource products for livelihoods and poverty alleviation in South Africa. PhD thesis, Rhodes University, Grahamstown, South Africa (2005): 101-120.

8. Hall J B. Sclerocarya birrea (A. Rich) Hoschst. Record from Protabase (2002).

9. Leakey R. "Domestication potential of Marula (Sclerocarya birrea subsp. caffra) in South Africa and Namibia: 3. Multiple traits selection". Agroforestry systems 64 (2005): 51-59.

10. Munondo R. Population dynamics of Marula, Sclerocarya birrea sub sp.caffra in Mwenezi, Zimbabwe: A thesis submitted in partial fulfilment of the requirements of a Master of Science Degree in Tropical Resources Ecology (MTRE): A thesis submitted in partial fulfilment of the requirements of a Master of Science Degree in Tropical Resources Ecology (MTRE) (2005).

11. Leakey R., et al. "Domestication potential of Marula (Sclerocarya birrea subsp. caffra) in South Africa and Namibia: 2. Phenotypic variation in nut and kernel traits". Agroforestry systems 64 (2005a): 37-49.

12. Orwa C., et al. Agroforestry tree Database: A tree reference and selection guide version 4.0 (2009). 
13. Mariod A A and Abdelwahab S I. "Sclerocarya birrea (Marula), an African tree of nutritional and medicinal uses: A review". Food Review International 28 (2012): 375-388.

14. Leakey R., et al. "Domestication potential of (Sclerocarya birrea subsp. caffra) in South Africa and Namibia: 1. Phenotypic variation in fruit traits". Agroforestry systems 64 (2005b): 25-35.

15. Shackleton S E and Shackleton C M. Use of marula products for domestic and commercial purposes by households in the Bushbuckridge district, Limpopo Province, South Africa. Unpublished report, Rhodes University, Grahamstown. (2002): 61.

16. Mojeremane W and Tshwenyane S O. "The Resource Role of Marula (Sclerocarya birrea): A Multipurpose Indigenous Fruit Tree of Botswana". Journal of Biological Sciences 4.6 (2004): 771-775.

17. Wynberg R., et al. "Knowledge on Sclerocarya birrea subsp. caffra with emphasis on its importance as a non-timber forest product in South and Southern Africa. Part 2: Commercial use, tenure and policy, domestication, intellectual property rights and benefit sharing". Southern African Forestry Journal 196 (2002): 67-77.

18. Chivaura-Mususa C., et al. "The value of mature trees in arable fields in the small-holder sector, Zimbabwe". Ecological Economics 33 (2000): 395-400.

19. Mutshinyalo $\mathrm{T}$ and Tshisevhe J. Sclerocarya birrea (A.Rich.) Hochst. Subsp. Caffra (Sond.) Kokwaro. Pretoria National Botanical Garden (2003).

20. Nyamapfene K. Soils of Zimbabwe, Nehanda Publishers; Harare (1991).

21. Palgrave K C. Trees of southern Africa, 3rd edition. Cape Town: Struik (2002).

Volume 2 Issue 8 August 2019

(C) All rights are reserved by Kugedera Andrew Tapiwa. 